\title{
Shallow Temperature Lapse Rate Signified Elevation Dependent Warming in Different Treeline Environments in the Himalaya- Possible Implications to Treeline Vegetation
}

\section{Rajesh Joshi ( $\nabla$ dr.rajeshjoshi@gmail.com )}

GBPIHED: Govind Ballabh Pant National Institute of Himalayan Environment and Sustainable

Development https://orcid.org/0000-0003-4287-9415

Ninchhen Dolma Tamang

GB Pant Institute of Himalayan Environment and Development: Govind Ballabh Pant National Institute of Himalayan Environment and Sustainable Development

\section{Surendra Pratap Singh}

Central Himalayan Environment Association, Dehradun, India

\section{Research Article}

Keywords: Temperature lapse rate, Elevation dependent warming, Climate, Growing season temperature, Alpine, Treeline, Himalayas

Posted Date: November 1st, 2021

DOI: https://doi.org/10.21203/rs.3.rs-912856/v1

License: (c) (i) This work is licensed under a Creative Commons Attribution 4.0 International License.

Read Full License 


\section{Abstract}

There are emergent evidences that the rise in temperature in high altitude regions in comparison to low altitude of the Himalaya is more rapid than other parts of the World. This Elevation-dependent warming (EDW) can accelerate the rate of change in mountain ecosystems, including cryosphere, hydrology, biodiversity and socio-economic systems. In this paper, we present Temperature Lapse Rates (TLRs) from 20 stations for three treeline transects representing different climate regimes along the Himalayan arc. TLRs were calculated based on high temporal resolution data collected for two year (2017-18) from complex mountain terrain of treeline environment. The annual mean TLR increased with decreasing moisture, being markedly high at dry WH transect $\left(-0.66^{\circ} \mathrm{C} / 100 \mathrm{~m}\right)$ and lowest $\left(-0.50^{\circ} \mathrm{C} / 100 \mathrm{~m}\right)$ for moist EH transect. The One-Way ANOVA confirms that the TLR varied spatially, declining from West to East across the Himalayan arc, and significantly differ among seasons $(F=3.2175 ; \mathrm{P}=0.03)$. The lowest mean TLRs were found during the winter season $\left(\mathrm{EH}:-0.46^{\circ} \mathrm{C} / 100 \mathrm{~m} ; \mathrm{CH}:-0.40^{\circ} \mathrm{C} / 100 \mathrm{~m} ; \mathrm{WH}:-0.31^{\circ} \mathrm{C} / 100 \mathrm{~m}\right)$. The monthly TLR varied within a narrow range $\left(-0.49^{\circ} \mathrm{C} / 100 \mathrm{~m}\right.$ to $\left.-0.54^{\circ} \mathrm{C} / 100 \mathrm{~m}\right)$ at $\mathrm{EH}$ transect, $-0.24^{\circ} \mathrm{C} / 100 \mathrm{~m}$ to $-0.68^{\circ} \mathrm{C} / 100 \mathrm{~m}$ at $\mathrm{CH}$ transect and from $-0.26^{\circ} \mathrm{C}$ to $-0.90^{\circ} \mathrm{C}$ at WH transect with lowest monthly TLR in December $\left(-0.24\right.$ to $\left.-0.32^{\circ} \mathrm{C} / 100 \mathrm{~m}\right)$ for all three sites. Study shows moisture, snow albedo and reflectance play a key role as controlling factors on TLR in treeline environments. Higher growing season temperatures observed for treelines in Himalaya $\left(8.4 \pm 1.8^{\circ} \mathrm{C}, 10.3 \pm 1.4^{\circ} \mathrm{C}\right.$, and $\left.7.5 \pm 2.7^{\circ} \mathrm{C}\right)$ shows warmer treeline in Himalaya. The EDW may impact the dynamics of treeline, snow and moisture regime, surface energy balance, increased water stress, species distribution, and growing season of alpine vegetation in the Himalaya. The findings of the study could provide useful insight (ground-based) to re-parameterize the climate models over the Himalayan region. This study can facilitate improving interpolation of air temperature for ecological modeling studies in ungauged and the data-sparse regions, especially for the higher Himalaya where ground based station data are extremely scarce.

\section{Introduction}

The Himalayan region, with the largest snow and ice cover mountainous region in the world, regulates climate of a large landscape in the South Asia. It is home to major river systems, largest cryosphere area outside the polar region, one of the global biodiversity hot spots, and support life of nearly 300 million people (Xu et al., 2009). This region also holds significant importance in terms of biological and sociocultural diversity, and encompasses wealth of a large number of endangered endemic species. This region is experiencing swift changes driven by climate change and other anthropogenic factors such as urbanization, infrastructure development, migration, tourism and globalization, which may lead to enormous consequences; both at regional and global level (Sharma et al., 2019). The rate of warming in Himalayas during past 102 years (1901-2003) in the last century has been higher $\left(0.9-1.6^{\circ} \mathrm{C}\right)$ than average global warming rate with relatively higher warming during the recent decades (Bhutiyani et al., 2007; Joshi and Kumar, 2013). Rise in both minimum and maximum temperatures has resulted into relatively warmer winters in the region (Dimri and Dash, 2012). Earlier studies have also reported enhanced warming in mountains with higher rates than land surfaces and greater increases in minimum 
temperatures than maximum temperatures (Diaz and Bradley, 1997; Beniston et al., 1997; Rangwala et al., 2009; Liu et al., 2009; Qin et al.; 2009).

There are growing evidences that the rate of warming is amplified with elevation; high elevation areas including alpine region experience higher increase in temperature than lower elevation areas (Pepin et al., 2015). This elevation-dependent warming (EDW) can modify various ecosystems in the mountain, including cryosphere, hydrological regimes and biodiversity. EDW is governed by important feedback mechanisms of snow, albedo, land surface, water vapor, latent heat release, and radiative flux changes, temperature change, and aerosols. Combinations of these factors may account for contrasting regional patterns of EDW (Rangwala and Miller, 2010; Rangwala and Miller, 2012; Pepin et al., 2015). The study from Tibetan Plateau by Yan and Liu, (2014) for 1961-2012 shows increase in warming rate with elevation for annual mean temperature and minimum temperatures, both at annually and during autumn and winter season. Similarly, EDW has been observed across other mountain regions (e.g. the Swiss Alps, the Colorado Rocky Mountains, the Tibetan Plateau, the Himalayas, and the Tropical Andes) in response to global or regional climate change (Pepin and Losleben, 2002; Rolland, 2003; Pepin and Seidel, 2005; Blandford et al., 2008; Liu et al., 2009; Qin et al., 2009; Rangwala and Miller, 2010; Gilbert and Vincent, 2013, Joshi et al., 2018). These studies confirm that high elevation regions including alpines are warming more rapidly than lowland areas across the world.

The high-altitude environments are influenced by the free atmosphere temperature gradients or temperature variation with altitude known as "temperature lapse rate (TLR)". TLR varies on daily and seasonal scales in mountains (Müller and Whiteman, 1988; Blandford et al., 2008; Joshi et al., 2018) due to local surface energy balance (Marshall et al., 2007) and different weather types or synoptic conditions (Pepin, 2001; Kirchner et al., 2013). It is useful for determining the elevational distribution of temperature along a transect in absence of the in-situ temperature measurements. In such cases, average temperature gradients of $-0.60{ }^{\circ} \mathrm{C}$ (Dodson and Marks, 1997) or $-0.65{ }^{\circ} \mathrm{C} / 100 \mathrm{~m}$ (Barry and Chorley, 1987) are often used to simulate and model various ecological processes when high precision is not required. However, temperature and precipitation gradients vary considerably with space and time and controlled by topographical features in mountains. Hence, assuming a constant value of TLR may lead to inaccurate results while examining elevation dependent warming and its impacts on different high-altitude ecosystems.

Studies on temperature gradients for treeline environments and other high-altitude ecosystems in Himalayan region are scarce (Shrestha et al., 1999). However, pioneering study by Joshi et al. (2018) gave initial estimates of TLR and its variation for treeline environment in Western Himalaya. The study showed that TLR for treeline in Himalayas, which varies seasonally and along aspect, is distinctly lower $\left(-0.53{ }^{\circ} \mathrm{C} / 100 \mathrm{~m}\right)$ than commonly used value. In recent decades, air temperature at higher elevations has increased more rapidly thereby decreasing near-surface air temperature lapse rates in warmer climate (Liu and Chen, 2000; Qin et al., 2009; Wang et al., 2005; Rangwala et al., 2010; Pepin, 2001). Hence, the lower value of mean TLR for treeline region in Western Himalaya may be due to the enhanced EDW in high altitude areas and a consequence of global warming. The existing knowledge gap in this domain calls for 
further studies to analyse seasonal and synoptic variations in TLRs for climatically sensitive environments such as treeline, alpine meadows, and cryosphere regions in Himalaya.

The major objective of the present study is to quantify the temperature lapse rate and examine spatial variations of mean annual, seasonal and monthly TLRs for treeline transects representing different climate regimes along Himalayan arc based on two year's in-situ instrumental records from 20 stations. Our study gives statistics of monthly and seasonal TLR for tree line environments within Indian part of Himalaya and explains the influence of important factors (air temperature, rainfall and relative humidity) on lapse rate. We further examined whether treelines in Himalayas are warmer than the other mountain ranges across the world and TLR for these environments in Himalaya are shallow than the commonly used values. We made efforts to explain that the EDW, signified by shallow TLRs, is amplified with elevation in Himalayan region under the influence of climate change. Considering that treeline environments are extremely temperature-sensitive transition zone for many plant species endemic to the region (Körner, 1998; Walther et al., 2005), we discuss possible implications of reduced or shallow TLR on treeline vegetation and future needs to increase understanding of Himalayan climate, their controlling mechanisms and impacts on critical ecosystems. Considering the existing knowledge gap in the region, this study is a major effort to analyze temperature lapse rate for treeline areas of Himalayas as the study used observed daily temperature data for two years and the sites encompass much of the Himalayan Arc and major variability in precipitation in the region. However, to achieve more reliable estimates of the lapse rate and explaining EDW as a consequence of climate change, denser station networks and longer observations are required across the Himalaya.

\section{Material And Methods}

\subsection{Study area}

The present study was carried out in three treeline transects along the Himalayan Arc; namely, DaksumSinthan transect in Western Himalaya (here after referred as WH transect); Chopta-Tungnath transect in Central Himalaya (here after referred as $\mathrm{CH}$ transect) and Yuksam-Dzongri transect in Eastern Himalaya (here after referred as EH transect) in Indian part of Himalayan region (Fig. 1).

These sites are representative of different climate regimes of Himalaya (Singh et al. 2017). The WH transect, located in Jammu \& Kashmir (India), represents a non-monsoonal site with low annual precipitation (State annual average $900 \mathrm{~mm}$ ) and moist pre-monsoon. Whereas $\mathrm{CH}$ transect, in Uttarakhand state in India, is a typical monsoon rainfall (June-September) dominated site (State annual average $1549 \mathrm{~mm}$ ) with dry pre-monsoon season. The EH transect, located in Sikkim state of India in Eastern part of Himalaya, is characterized with extended monsoon season (April-September), moist pre monsoon and relatively dry winter season (State annual average rainfall $2684 \mathrm{~mm}$ ). The treeline in these transects is found ranging between $3400-4000 \mathrm{~m}$ asl and tended to increase from the west to east, largely because of decreasing latitude. Climatic characteristics of three study transects is presented in Table 1.

Table 1. Climatic characteristics of three study transect in Indian Himalayan region 


\begin{tabular}{|c|c|c|c|}
\hline Parameter & $\begin{array}{l}\text { WH transect } \\
\text { (Kashmir, } \\
\text { Western } \\
\text { Himalaya) }\end{array}$ & $\begin{array}{l}\mathrm{CH} \text { transect (Uttarakhand, } \\
\text { Central Himalaya) }\end{array}$ & $\begin{array}{l}\text { EH transect (Sikkim, Eastern } \\
\text { Himalaya) }\end{array}$ \\
\hline $\begin{array}{l}\text { Annual Mean } \\
\text { Temeprature }\end{array}$ & $7.8 \pm 6.6^{\circ} \mathrm{C}$ & $10.5 \pm 4.2^{\circ} \mathrm{C}$ & $8.6 \pm 3.6^{\circ} \mathrm{C}$ \\
\hline $\begin{array}{l}\text { Mean } \\
\text { growing } \\
\text { season } \\
\text { temperature }\end{array}$ & $8.4 \pm 1.8^{\circ} \mathrm{C}$ & $10.3 \pm 1.4^{\circ} \mathrm{C}$ & $7.5 \pm 2.7^{\circ} \mathrm{C}$ \\
\hline $\begin{array}{l}\text { Precipitation } \\
\text { pattern } \\
\text { (State } \\
\text { annual } \\
\text { average } \\
\text { precipitation) }\end{array}$ & $\begin{array}{l}\text { Low annual } \\
\text { precipitation } \\
\text { (approx. } 990 \\
\text { mm) with moist } \\
\text { pre-monsoon } \\
\text { (March- May) }\end{array}$ & $\begin{array}{l}\text { Moderate annual precipitation } \\
\text { (approx. } 1549 \text { mm) with dry pre- } \\
\text { monsoon season (March- May) } \\
\text { and monsoon (June- } \\
\text { September) rainfall dominated }\end{array}$ & $\begin{array}{l}\text { High annual precipitation } \\
\text { (approx. } 2684 \mathrm{~mm} \text { ) with } \\
\text { extended monsoon season } \\
\text { (April- September) and and } \\
\text { relatively dry winter season }\end{array}$ \\
\hline
\end{tabular}

\subsection{Meteorological Setup and Data}

To estimate the TLR and its spatial variations over the study transect, 5 portable ONSET HOBO Pro-V2 temperature loggers, covered with radiation shield, were installed along $\mathrm{WH}$ transect, 10 along $\mathrm{CH}$ transect, and 6 along EH transect (Table 2). The number of stations across the three sites differed because of availability of suitable and safe sites with security arrangement for safeguarding the loggers and other instruments. Further, an advanced AWS consisting of Campbell SR50A sonic ranging sensor, ARG100 tipping bucket with HOBO event data logger, temperature probe (109-L), soil moisture sensor, anemometer, solar radiation sensor, and 6 ARG-100 tipping bucket rain gauges (Waterlog make; 8" dia.) was also installed at $3300 \mathrm{~m}$ asl within $\mathrm{CH}$ transect.

Table 2. Details of the meteorological stations along with altitude (in masl) located along three study transect in Indian Himalayan region 


\begin{tabular}{|llllll|}
\hline CH Transect & & WH Transect & \multicolumn{2}{l|}{ EH Transect (Sikkim) } \\
\hline Station & Altitude & Station & Altitude & Station & Altitude \\
\hline Ukhimath & 1500 & Kokarnag & 1900 & Yuksam & 1700 \\
\hline Siroli & 1600 & Daksum & 2400 & Sachen & 2225 \\
\hline Taala & 1820 & Arkhani & 2563 & Bakhim & 2649 \\
\hline Mandal & 2100 & Bampathri & 2973 & Tsokha & 3002 \\
\hline Dugalbhitta & 2500 & Sinthan & 3900 & Phedang & 3690 \\
\hline Kanchulakharak & 2675 & & & Dzongri & 4000 \\
\hline Chopta & 2870 & & & & \\
\hline Saukharak & 3100 & & & & \\
\hline Tungnath & 3360 & & & & \\
\hline Chandrashila & 3680 & & & & \\
\hline
\end{tabular}

Data from the temperature sensors and raingauge was recorded at 30-minute interval. The observed data were analysed for 2017 and 2018 for different months and climate seasons; namely, Winter (DecemberFebruary), Pre-monsoon (March-May), Monsoon (June-September), and Post-monsoon (OctoberNovember). Within the study transect, the winter season at high altitude is chareterized by the lowest temperatures and precipitation mostly in the form of snow. The pre-monsoon season is chareterized by relatively high temperatures gradually increasing till the onset of monsoon. During this period, high variability in diurnal temperature and scanty rainfall are observed. During the monsoon season heighest amount of rainfall is received along with relatively high temperature, and charecteristically low diurnal varibility. A steady decrease in temperature alongwith less amount of rainfall is the key feature of winter season along these transects.

\subsection{Method}

The Pearson's correlation coefficient was calculated between observed monthly mean temperature and elevation of the station and the significant correlation coefficients were considered for further analysis. Correlation analysis was carried out to estimate the measure of the strength of the linear relationship between the two variables. The Pearson Correlation Coefficient $(r)$ between Temperature $(T)$ and Elevation $(z)$ is expressed as:

$r(T, Z)=\frac{1}{n} \sum_{i=1}^{n}\left(\frac{T_{i}-\bar{T}}{S_{T}}\right)\left(\frac{z_{i}-z}{S_{z}}\right)$ 
Where $\bar{T}$ and $S_{T}$ represents mean and standard deviation values for temperature, respectively, whereas $\bar{z}$ and $S_{T}$ are the mean and standard deviation values for elevation. A high values of correlation coefficient represent strong linear relationship between the elevation and the temperature whereas small value of $r$ shows a week liner relationship between the variable (Joshi et al., 2018).

Under well-mixed atmospheric boundary conditions air temperature often decreases/increases linearly with elevation (Lundquist et al., 2008). Hence, following Joshi et al. (2018), TLRs ( $\left.{ }^{0} \mathrm{C} / 100 \mathrm{~m}\right)$ were estimated by developing a gradient using all point level observations of mean temperature and elevation by using following equation:

$$
L R=\frac{T_{1}-T_{2}}{z_{1}-z_{2}}=\frac{d T}{d z}
$$

Where $T_{1}$ and $T_{2}$ are the air temperature of the two stations (in ${ }^{0} \mathrm{C}$ ), and $\mathrm{z}_{1}$ and $\mathrm{z}_{2}$ represents respective elevation $(\mathrm{m})$. Considering the fact that temperature in mountains varries topographcally in different months and seasons (Barry, 1992), TLRs were calculated separately for all the months well as for each of four seasons; viz. pre-monsson (MAM)), monsoon (JJAS), post-monsoon (ON), and winter (DJF). Statistical analyses were performed to test the significance of results obtained. At first, independent sample t-test was used to test the significance of difference in TLR among the sites. Subsequently, oneway analysis of variance (ANOVA) was used to compare the monthly and seasonal TLRs between different study transects. Both the tests were applied at significance alpha level $a=0.05$ (or $\mathrm{Cl}=95 \%$ ) and $p$ values $(p<0.05)$ using STATISTICA 8.0. To analyze the factors for seasonal variation in TLRs, relationship of TLR with two other climatic parameters (i.e. rainfall and relative humidity) was studied statistically. Since, rainfall and relative humidity data ware not available for the WH transect and EH transect, therefore, analysis was carried out for $\mathrm{CH}$ transact as a case study only. Based on the observed temperature data, saturation vapour pressure $\left(e_{s}\right)$ lapse rate was calculated for $\mathrm{CH}$ transect using the equation based on the Clausius-Claperon relationship (Tetens, 1930).

\section{Results}

Analysis of correlation coefficient show that the correlation between monthly mean temperature and elevation was significantly negative at $p<0.01$ and $p<0.05$ for all months across all three sites (Table 2). The lowest correlations were for the winter months, where $r$ varied between 0.79 and 0.96 , when temperatures were found to be lowest in all three transects. The heighest values of correlation coefficient between monthly mean temperature were estimated for the duration May to September. Lower correlation coefficients between the temperature during summer months and elevation are attributed to frequent monsoon rainfall events at each sites (Joshi et al., 2018).

\subsection{Variation in annual TLRs across three sites}


The annual TLR increased from moist to dry sites, the value being $-0.50^{\circ} \mathrm{C} / 100 \mathrm{~m},-0.52^{0} \mathrm{C} / 100 \mathrm{~m}$ and $-0.66^{\circ} \mathrm{C} / 100 \mathrm{~m}$ for $\mathrm{EH}$ transect, $\mathrm{CH}$ transect and $\mathrm{WH}$ transect, respectively (Fig. 2). It increases with decreasing moisture, being markedly higher at WH transect of Kashmir part of Himalaya. The annual mean TLR was found lowest for EH transect in Sikkim, which is largely moist in comparison to other two sites. The annual mean TLRs for $\mathrm{EH}$ transect and $\mathrm{CH}$ transect in the Eastern and Central Himalaya, respectively, are distinctly lower than the commonly used value of $-0.65^{\circ} \mathrm{C} / 100 \mathrm{~m}$ (Barry and Chorley 1987). Wehereas, for the WH transect located in the Western part of Himalaya, slightly higher TLR was found. The results showed that the TLR varies spatially and decreases from West to East in Himalaya, and is dissimilar for different precipitation regimes in the Himalaya.

\subsection{Monthly and Seasonal variation in TLRs across three transects}

At all the study sites the lowest monthly TLR was in December (Table 3). However, TLR for the three sites differed in terms of the seasonal pattern. At EH transect the monthly TLR varied within a narrow range, $-0.49^{\circ} \mathrm{C}$ to $-0.54^{\circ} \mathrm{C}$, except in December when it dropped to $-0.32^{\circ} \mathrm{C}$ from $-0.53^{0} \mathrm{C}$ in November (Fig. 3). For $\mathrm{CH}$ transect the monthly TLR varied to an extent from $-0.24^{\circ} \mathrm{C}$ (in December) to $-0.68^{\circ} \mathrm{C}$ (in May), and the values were constantly high during pre-monsoon months $\left(-0.63^{\circ} \mathrm{C}\right.$ to $\left.-0.68^{\circ} \mathrm{C}\right)$, whereafter it decreased to an intermediate level during monsoon months $\left(-0.49^{\circ} \mathrm{C}\right.$ to $\left.-0.63^{\circ} \mathrm{C}\right)$ subsequently it decreased sharply from October $\left(-0.51^{\circ} \mathrm{C}\right)$ to December $\left(-0.24^{\circ} \mathrm{C}\right)$ (Fig. 4). In contrast at WH site, TLR ranged widely from $-0.26^{\circ} \mathrm{C}$ to $-0.90^{\circ} \mathrm{C}$. It decreased sharply from $-0.78^{\circ} \mathrm{C}$ in October to $-0.26^{\circ} \mathrm{C}$ in December (a fall of $-0.52^{\circ} \mathrm{C}$ ), where after it increased and values were moderately high $\left(-0.62^{\circ} \mathrm{C}-0.64^{0} \mathrm{C}\right)$ during the dry pre-monsoon months (April-June) (Fig. 5). At this site it peaked in August and was high until October. Compared to the other two sites, WH was relatively drier, with no distinct dry and moist seasons, the precipitation varying from $24 \mathrm{~mm}$ (November) to $11 \mathrm{~mm}$ (March).

Table 3. Monthly TLR $\left({ }^{\circ} \mathrm{C} / 100 \mathrm{~m}\right)$ values and Correlation coefficient $(r)$ between mean temperature and elevation for three study sites across the IHR 


\begin{tabular}{|c|c|c|c|c|c|c|}
\hline \multirow[t]{2}{*}{ MONTH } & \multicolumn{2}{|c|}{ WH Transect } & \multicolumn{2}{|c|}{$\mathrm{CH}$ Transect } & \multicolumn{2}{|c|}{ EH Transect } \\
\hline & TLR & $R$ & TLR & $r$ & TLR & $r$ \\
\hline JANUARY & -0.3 & $-0.86^{\star \star}$ & -0.42 & $-0.94^{\star}$ & -0.54 & $-0.87^{\star \star}$ \\
\hline FEBRUARY & -0.38 & $-0.89 \star \star$ & -0.52 & $-0.96^{\star}$ & -0.53 & $-0.91^{\star}$ \\
\hline $\mathrm{MARCH}$ & -0.54 & $-0.94^{\star}$ & -0.63 & $-0.95^{\star}$ & -0.52 & $-0.92^{\star}$ \\
\hline APRIL & -0.64 & $-0.93^{\star}$ & -0.67 & $-0.98^{\star}$ & -0.53 & $-0.93^{\star}$ \\
\hline MAY & -0.63 & $-0.95^{\star}$ & -0.68 & $-0.99 *$ & -0.52 & $-0.94^{\star}$ \\
\hline JUNE & -0.62 & $-0.97 *$ & -0.63 & $-0.99 *$ & -0.5 & $-0.96^{\star}$ \\
\hline JULY & -0.65 & $-0.98 *$ & -0.52 & $-0.99 *$ & -0.51 & $-0.95^{\star}$ \\
\hline AUGUST & -0.9 & $-0.91 *$ & -0.49 & $-0.98^{*}$ & -0.5 & $-0.94^{\star}$ \\
\hline SEPTEMBER & -0.8 & $-0.92^{*}$ & -0.54 & $-0.98^{*}$ & -0.49 & $-0.95^{\star}$ \\
\hline OCTOBER & -0.78 & $-0.86 \star \star$ & -0.51 & $-0.97^{\star}$ & -0.52 & $-0.93^{\star}$ \\
\hline NOVEMBER & -0.34 & $-0.85^{\star \star}$ & -0.38 & $-0.94^{\star}$ & -0.53 & $-0.92^{\star}$ \\
\hline DECEMBER & -0.26 & $-0.79 \star \star$ & -0.24 & $-0.83^{\star \star}$ & -0.32 & -0.81 ** \\
\hline
\end{tabular}

*Correlation values significant at $P<0.01$; *Correlation values significant at $P<0.05$.

The highest mean TLR values were observed during pre-monsoon months at $\mathrm{EH}\left(-0.66^{\circ} \mathrm{C} / 100 \mathrm{~m}\right)$ and $\mathrm{CH}$ sites $\left(-0.52^{\circ} \mathrm{C} / 100 \mathrm{~m}\right)$ (Fig. 6; Table 4). Because of the absence of clouds and higher temperature during pre-monsoon, land surfaces receive more incoming solar radiation compared with outgoing radiation. This resulted in a rise in day time surface temperatures and large sensible heat flux which presumably enhanced strong dry convection in the daytime. The pre-monsoon season also had the highest daytime saturation varour pressour $\left(e_{s}\right)$ lapse rate; as a result, the TLR reached a maximum value in that season. The lowest mean TLR values were observed during winter season (DJF) on all the transects (EH: $-0.46^{\circ} \mathrm{C} / 100 \mathrm{~m} ; \mathrm{CH}:-0.41^{\circ} \mathrm{C} / 100 \mathrm{~m}$; WH: $-0.31^{\circ} \mathrm{C} / 100 \mathrm{~m}$ ) which implies that snow albedo or reflectance play a more important role as controlling factors on TLR. The One-Way ANOVA confirms that the TLR varied significantly across all the sites and significantly differ among seasons ( $\mathrm{F}=3.2175 ; P=0.03)$ indicating that the seasons have strong influence on TLR. These results are also in agreement with shallow TLRs estimated by Tang and Fang (2006), Kattel et al. (2013), Immerzeel et al. (2014), Kattel et al. (2015) and Joshi et al. (2018) for other parts of Himalaya.

Table 4. Seasonal mean TLR for the three study transects acorss the Himalaya 


\begin{tabular}{|llll|}
\hline Season & EH Transect & CH Transect & WS Transect \\
\hline DJF & -0.46 & -0.41 & -0.31 \\
\hline MAM & -0.52 & -0.66 & -0.60 \\
\hline JJAS & -0.50 & -0.53 & -0.62 \\
\hline ON & -0.52 & -0.47 & -0.70 \\
\hline
\end{tabular}

\subsection{Relationship of TLR with rainfall and Relative Humidity}

Statistical relationship of TLR with rainfall and saturation vapour pressure lapse rate was analyzed to examine reason for seasonal variation in TLR. Based on the analysis of climate data for $\mathrm{CH}$ transect (Fig. $7 \& 8)$, regression between mean TLR and rainfall $r=-0.27\left(R^{2}=0.073\right)$ showed inverse pattern of relationship between daily rainfall and TLR in the annual variability. It suggests that variation in TLR for some of the seasons were not consistently associated with rainfall. Further, annual cycle of mean saturation vapor pressure $\left(e_{s}\right)$ lapse rates for $\mathrm{CH}$ transect was analysed. The $e_{s}$ lapse rate was calculated to examine the relationship between TLR and humidity as factor. The correlation between mean TLR and $e_{s}$ lapse rate exhibited a statistically significant positive relationship $(r=0.63, p<0.05)$, which indicates that variation in TLR was consistently associated with variations in $e_{s}$ lapse rate in all seasons. The mean $e_{s}$ lapse rate was lowest $(-20.15 \mathrm{hPa} / 100 \mathrm{~m}, \mathrm{r}=-0.96$, and $\mathrm{p}<0.0001)$ in January and highest $(-77.55$ $\mathrm{hPa} / 100 \mathrm{~m}, \mathrm{r}=-0.95$, and $\mathrm{p}<0.0001)$ in May. The value remained nearly constant during monsoon months. This explain effects of dry and moist conditions in enhancing (in pre-monsoon season) and reducing (in monsoon season) TLR (Joshi et al., 2018). Hence, the atmosphere water vapor content and its seasonal variations could play an important role in forcing the variations in lapse rate. The atmospheric water vapor during winter season is mostly lower than the monsoon season and generally, the higher elevation areas have lower specific humidity across the year (Thayyen and Dimri, 2014).

\section{Discussion}

A comparison of the three sites indicates that TLR was generally lower in humid and cooler conditions, and higher in drier and warmer conditions. In eastern Himalaya, conditions are moist during most of the period of a year, and TLR for EH transect was almost invariant during entire year, except in December when it was low resulting in little variations in TLR during most of the year. While at the strongly monsoonal climate with distinctly dry pre-monsoon period in western Himalaya, TLR showed a sharp drop from pre-monsoon to monsoon period. During pre-monsoon season, when cloud cover is negligible, land surfaces receive more incoming solar radiation than the outgoing radiation that increases daytime surface temperatures (Blandford et al., 2008). This results in enhanced sensible heat flux and cause strong dry convection in the daytime. Therefore, increase in sensible heat flux together with high daytime saturation varour pressour $\left(e_{s}\right)$ lapse rate result in the maximum TLR in pre-monsoon season (Kattel et al., 2013). 
Relatively lower values of TLRs were observed during the months July-September. During this period the air over, high elevations is warmed by latent heat release associated with water vapor condensation, thereby reducing the lapse rate. Latent heat transfers depend on moisture content in the atmosphere (Marshall et al., 2007). In response to heavy summer rainfall, surface temperatures decrease and moist adiabatic processes prevail (Thyer, 1985). Thus, the relatively stable lapse rate of temperature during monsoon months implies a strong association with rainfall amount. Surface temperature oscillations also depend on cloudiness, which results to marked variability in TLR even within the same season. For example, during the winter, TLR fluctuated from nearly 0 to $-0.8^{\circ} \mathrm{C} / 100 \mathrm{~m}$ from day-today. Monsoon months (July-September) were however, characterized by relatively steady TLR on a day-to-day basis, varying mostly between -0.3 and $-0.6^{\circ} \mathrm{C} / 100 \mathrm{~m}$. Because elevations considerably vary within a short distance in mountains, on some days weather condition may remain similar across a wide elevation range, however, on some other days it is finely divided in layers. Significant cloud cover leads to a reduction in insolation during the day and a confinement of outgoing long-wave radiation during the night (Bhutiyani et al., 2007), thereby increasing minimum surface temperatures. Therefore, cloudy skies and moist conditions may reduce the daytime TLR value and enhance the nighttime TLR, minimizing the difference between the TLR associated with maximum and minimum temperatures.

However, during October and November months (post-monsoon season), the mean TLR is lower compared to dry and warm months (April-June) but higher compared with the December-February months (i.e. winter season) and July-September months (i.e. monsoon seasons). During these months weather conditions are similar to pre-monsoon conditions, but the thermal forcing effect is relatively small due to the disturbances between the phase of monsoon retreat and the onset of winter westerlies. The lowest mean TLR value occurring in winter implies other controlling factors such as snow and albedo play a more important role. During winter, skies are clear and radiative cooling is intense, leading to a stable stratification and producing a temperature inversion (Critchfield, 2004). This condition facilitates the development of microclimates (Thyer, 1985) and cold air deposition in low areas through down slope flow at the flat terrain and valleys known as temperature inversion (Rolland, 2003) which is further enhanced by foggy conditions during winter season.

\subsection{A major effect of elevation-dependent warming}

TLR was constantly low during monsoon months (particularly July-August), resulting in a negative correlation with rainfall $\left(r=-0.27 ; R^{2}=0.07\right)$. It kept on decreasing during autumn and the lowest was in December at all sites. It gradually increased after December, except for the $\mathrm{CH}$ transect where it increased sharply, and the highest being during pre-monsoon months (April-May) when humidity was the lowest. TLR was comparatively low in humid and cooler conditions, and higher in drier and warmer conditions which is confirmed by a statistically significant positive relationship $(r=0.63, p<0.05)$ existing TLR and $\mathrm{e}_{\mathrm{s}}$ lapse rate. The elevation dependent warming (EDW) (Wester et al., 2019) and change in snow cover could have resulted in the lowest TLR in December. Because of the more warming of cool high elevation areas and less warming of low elevation areas, TLR is expected to have decreased due to global warming 
(Fig. 9). This differential warming rate is higher during the winter season, particularly in December, when snowfall is still sparse and alpine meadow vegetation is dead and dark, resulting in a sharp decrease in albedo. In Himalayas, the winter warming rate has been greater than other seasons (Bhutiyani et al., 2007; Joshi and Kumar, 2013). The EDW effect is generally high during winter season (Giorgi et al., 1997; Bradley et al., 2004; Yan et al., 2016; Palazzi et al., 2017). Enhanced warming at higher elevations, particularly during winter, largely because of snow-albedo feedback, has been reported in a few other studies (e.g., Im and Ahan, 2011; Pepin et al., 2015). The snowfall in January and February would have increased the albedo and reduced temperature in high elevation areas, resulting in increase in TLR during these months.

Figure 9. Factors causing decrease in December TLR in Himalayas

Seasonal changes in temperatures indicate that the decline in temperature from autumn months to December was less in higher ranges than lower ranges. For $\mathrm{CH}$ transect, the effect of darkened vegetation and reduced albedo in meadow in December is also reflected in lower TLR across alpine meadow sites (TLR was $-0.18^{\circ} \mathrm{C} / 100 \mathrm{~m}$ above treeline) than across forest sites (TLR was $-0.6^{\circ} \mathrm{C} / 100 \mathrm{~m}$ below treeline). In brief, TLR is the lowest due to EDW and high albedo in December. It is moderately low during wet monsoon months when the humidity is uniformly high. In recent years, aerosol concentration has increased, and it is more in lower elevation areas, which are closer to the plains where some of the largest and most polluted cities of India are located (Wester et al., 2019). Aerosols contribute to reducing temperature by solar dimming. There are not enough past estimates of TLR to ascertain whether TLR has decreased as a result of global warming. However, the fact that EDW is well established in Himalayas, there is more warming during winter season in Himalayas, and winter TLR values are the lowest in our study indicate this role of global warming in modifying TLR.

\subsection{Relationship between TLR and Treeline in Himalaya}

For 2017 and 2018 , the mean growing season temperature at treeline were found as $8.4 \pm 1.8^{\circ} \mathrm{C}, 10.3 \pm$ $1.4^{\circ} \mathrm{C}$, and $7.5 \pm 2.7^{\circ} \mathrm{C}$ for $\mathrm{WH}, \mathrm{CH}$ and $\mathrm{EH}$, respectively. This shows that the observed growing season temperature for treeline in Himalaya is much higher than growing season temperatures $\left(6.5 \pm 0.8^{0} \mathrm{C}\right)$ defined based at a global level (Körner and Paulsen, 2004). This further confirms pronounced warming at high elevation areas and hence EDW signified by shallow TLRs across Himalayan region. Since the Himalayan treelines are unable move up (Sah and Sharma, 2018), they are getting warmer for last several decades of global warming with several consequences for ecosystem services.

The location of the Himalayan treeline is usually governed by growing season air temperature combined with topographic factors (Korner and Larcher, 1988). In a mountain ecosystem, low temperature is the main controlling factor of alpine zone. Under warmer and drier conditions treeline vegetation could be affected adversely by increased evapotranspiration and water stress (Kitayama, 1996). Snow cover, often correlated with mean temperature and precipitation, not only provides protection to alpine plant communities from frost during winter season (Körner, 1999) but also supply water during spring season for initiating their growth during a relatively short growing season. Therefore, EDW signified by shallow 
TLRs may have several possible implications to treeline dynamics, and tree species distribution in Himalaya. Under warmer conditions, Treeline can go higher provided suitable habitat for treeline species is available. As a consequence of low temperature lapse rates, relatively high mean growing season temperature, and subsequent elevation dependent warming, vegetation communities growing in snow beds may be subjected to summer desiccation (Korner and Larcher, 1988; Cannone et al., 2007). Thus loss of potential habitats of many threatened plant species and increase in the plant cover of dwarf shrubs in alpine regions (Cannone et al., 2007), and increase in species richness at summits (Pauli et al., 2007) could be the likely effect of EDW.

Further, because of EDW, the upwards migration of the treeline would significantly alter the surface characteristics and local climate of alpine regions by modifying the albedo and surface energy balance (Fitzharris et al., 1996) resulting in possibility of new assemblages of plant and animal species in these regions. Furthermore, EDW may also modify the frequency of fire outbreaks as forests tend to transpire most of the available soil moisture under dry and warm conditions (Stocks et al., 1998). Hence, prolonged dry and warm season would exceed environmental and biological thresholds for fire outbreaks and consequently convert fire sensitive areas into regions of sustained fire hazard (Johnson, 1992). Therefore, it is presumed that the response of ecosystems to EDW in treeline zones will be extremely vital at ecotones in terms of the loss of the coolest climatic zones and upslope shift of ecotone vegetation.

\section{Conclusion}

Based on the in-situ temperature records from 20 stations across the Himalayan arc, we find relatively shallow mean annual TLRs for moist (EH site) and moderately moist sites in Himalayas than the frequently used average TLR value $\left(-0.65^{\circ} \mathrm{C} / 100 \mathrm{~m}\right)$. Low values of TLRs were also estimated by earlier researchers (Tang and Fang, 2006; Immerzeel et al., 2014; Kattel et al., 2015; Joshi et al., 2018) for different regions of Himalaya. The observed shallow TLRs, supported with earlier studies, suggests that the warming in high elevation regions is more pronounced than in lowland areas and indicates elevation dependent warming (EDW) in Himalaya under the influence of climate change. However, in the relatively drier and non-monsoonal climate (WH) TLR was higher. This could be partly related to intensified westerlies during recent years in Karakoram and parts of western Himalaya where increase in westerlies has lead to cooler temperature and stable snow cover and glaciers (Bookhagen and Burbank, 2010).These changes might have cancelled out EDW effect in Karakoram and parts of western Himalaya.

We find high variation in TLRs on annual, seasonal and monthly scale. The lowest mean TLR occurred in the month of December for all the sites. During this period, the sky mostly remains clear but intense radiative cooling leads to a stable stratification, producing a temperature inversion. The lowest TLR in December could be due to pronounced EDW, change in snow cover and sharp decrease in albedo during winter season. Because of the more warming in high elevation areas than the less warming of warm lower ranges, TLR is expected to further decrease due to the effect of global warming. Hence, the winter TLR is governed by snow- albedo feedback mechanism. In high altitude areas of Himalayan region high snowfall occurs during January and February which leads to increase in albedo and decline in air 
temperature in high elevation areas; this results into increase in TLR during the same months. The monthly variations in TLR were not uniform across all three sites. Relatively lower lapse rates were observed in humid or cooler atmospheric conditions, than in dry conditions. The observed variability in TLRs advocates for use of seasonally varying lapse rates while studying climate change impact on different ecosystems along altitudinal gradient In Himalaya.

The observed TLR showed that the elevation gradient of temperature increases from moist in Eastern Himalaya to dry sites in Central and Western Himalaya. In monsoon rainfall dominated or moist sites, TLR varied within a narrow range. The study further showed that the TLR varies spatially and temporarilly from East to West in Himalaya, and is dissimilar for different precipitation regimes. This study showed that inverse pattern of relationship $\left(r=-0.27 ; R^{2}=0.073\right)$ exists between annual variability of daily rainfall and TLR. However, a statistically significant positive relationship $(r=0.63, p<0.05)$ between annual cycle of mean saturation vapor pressure $\left(e_{s}\right)$ lapse rates and TLR confirm that the variation in TLR is controlled by moisture or relative humidity.

Because treelines are generally stationary despite decades of global warming, they are getting warmer, the long term effect of global warming on such arrested treelines need to be monitored. Such a condition may result in densification of treelines and eventually in mass mortality of trees due to soil desiccation. The lower values of TLR may have several possible impacts on the dynamics of treeline ecotone in Himalaya, such as change in snow and moisture regime, increased evapotranspiration and water stress, change in albedo and surface energy balance resulting to modify distribution patterns, range shift and growing season of alpine vegetation. The decrease in TLR would reduce the temperature range in a given elevation range, enhance the upper elevation limit of vegetation and species, leaving increasingly narrower belts for survival of plants and snow covered systems. The restricted space may limit a species to form viable population to achieve upward shift. This study made a noteworthy effort to analyze temperature lapse rate of treeline region of Himalayas based on observed daily for two years. However, a dense network of weather observation and long term data are required to achieve more consistent estimates of the lapse rate which could explain EDW as a consequence of climate change across the Himalayan region.

\section{Declarations}

\section{Acknowledgements:}

We acknowledge the funding support received from the Ministry of Environment, Forest and Climate Change, Government of India under National Mission on Himalayan Studies (Ref no: NMHS/LG$2016 / 009 ; 31.03 .2016)$ to conduct the research. We thank the Director, NIHE for providing necessary facilities for conducting the research. Contribution made by Mr. B. S. Bisht towards installation and maintenance of sensors in harsh conditions, and data collection is greatly acknowledged. Support received from Project Management Unit at CHEA, Forest Departments of Government of J\&K, Uttarakhand, and Sikkim and Director, HAPPRC, Srinagar is duly acknowledged. One of authors is 
thankful to Indian National Science Academy, New Delhi, India and Central Himalayan Environment Association (CHEA), Nainital, India.

Ethics approval and consent to participate- Not applicable

Consent for publication- Not applicable

\section{Availability of data and materials}

The datasets generated and/or analysed during the current study are not publicly available due Intellectual Property Right (IPR) but are available from the corresponding author on reasonable request.

Competing interests: The authors declare that they have no competing interests

Funding: The funding support for the present study was provided by Ministry of Environment, Forest, Climate Change (MoEFCC) Government of India under National Mission on Himalayan Studies wide Ref no: NMHS/LG-2016/009, Dated: 31-03-2016 for conducting the research.

\section{Authors' contributions}

Dr. Rajesh Joshi formulated project, conceptualized the study, Installed data loggers and other instruments, analyzed the data, collated the results and drafted the manuscript. Ms. Ninchhen Dolma Tamang synthesized and analyzed data from all the stations and the three sites. Prof. Surendra Pratap Singh helped in conceptualization of the idea and the study, interpretation of results and finalization of the manuscript writing.

Authors' information (optional): Has been provided at the beginning of the manuscript

\section{References}

1. Barry RG (1992) Mountain Weather and Climate. Routledge, London, p 402

2. Barry RG, Chorley RJ (1987) Atmosphere, Weather and Climate, 5th Edn. Routledge: London, 448 pp

3. Beniston M (1997) Variations of snow depth and duration in the Swiss Alps over the last 50 years: links to changes in large-scale Climatic forcings. Clim Chang 36:281-300

4. Bhutiyani MR, Kale VS, Pawar NJ (2007) Long term trends in maximum, minimum and mean annual temperatures across the northwestern Himalaya during the twentieth century. Clim Change 85:159177

5. Blandford TR, Humes KS, Harshburger BJ, Moore BC, Walden VP, Ye H (2008) Seasonal and synoptic variations in near-surface air temperature lapse rates in a Mountainous basin. $\mathrm{J}$ Appl Met Climatol 47:249-261

6. Bookhagen and Burbank (2010) Toward a complete Himalayan hydrological budget: Spatiotemporal distribution of snowmelt and rainfall and their impact on river discharge. J Geophy Res 115:1-25 
7. Bradley RS, Keimig FT, Diaz HF (2004) Projected temperature changes along the American cordillera and the planned GCOS network. Geophys Res Lett 31:L16210

8. Cannone N, Sgorbati S, Guglielmin M (2007) Unexpected impacts of climate change on alpine vegetation. Front Ecol Environ 5(7):360-364

9. Critchfield HJ (2004) General Climatology, 4th Edn. Prentice-Hall of India Pvt. Ltd., New Delhi

10. Diaz HF, Bradley RS (1997) Temperature Variations during the Last Century at High Elevation Clim. Change 36:253-279

11. Dimri AP, Dash SK (2012) Wintertime climatic trends in the Western Himalayas. Clim Chang $111: 775-800$

12. Dodson R, Marks D (1997) Daily air temperature interpolated at high spatial resolution over a large mountainous region. Clim Res 8(1):1-20

13. Fitzharris BB, Allison I, Braithwaite RJ, Brown J, Foehn P et al (1996) The Cryosphere: Changes and their Impacts. In: Second Assessment Report of the Intergovernmental Panel on Climate Change (IPCC). Cambridge University Press, pp 241-265

14. Friedland AJ, Boyce RL, Vostral CB, Herrick GT (2003) Winter and early spring microclimate within a mid-elevation conifer forest canopy. Agri Fores Met 115:195-200

15. Gilbert A, Vincent C (2013) Atmospheric temperature changes over the 20th century at very high elevations in the European Alps from englacial temperatures. Geophys Res Lett 40:2102-2108

16. Giorgi F, Hurrell J, Marinucci M, Beniston M (1997) Elevation dependency of the surface climate change signal: a model study. J Clim 10:288-296

17. Im ES, Ahn JB (2011) On the elevation dependency of present-day climate and future change over Korea from a high resolution regional climate simulation. J Met Soc 89:89-100

18. Immerzeel WW, Petersen L, Ragettli S, Pellicciotti F (2014) The importance of observed gradients of air temperature and precipitation for modeling runoff from a glacierized watershed in the Nepalese Himalayas. Wat Res Res 50:2212-2226

19. Johnson EA (1992) Fire and Vegetation Dynamics. Studies from the North American Boreal Forest. Cambridge University Press, Cambridge

20. Joshi R, Kumar K (2013) Analysis of long term climate variability and changes in North-Western states of Indian Himalayan Region (IHR). In: Sundaresan J, Gupta P, Santosh KM, Boojh R (Eds.), Climate Change and Himalaya-Natural Hazards and Mountain Resources, Scientific Publisher, New Delhi, India. pp. 130-148

21. Joshi R, Sambhav K, Singh SP (2018) Near surface temperature lapse rate for treeline environment in western Himalaya and possible impacts on ecotone vegetation. Trop Ecol 59(2):197-209

22. Kattel DB, Yao T, Yang K, Tian L, Yang G, Joswiak D (2013) Temperature lapse rate in complex mountain terrain on the southern slope of the central Himalayas. The Appl Climatol 113(3-4):671682 
23. Kattel DB, Yao T, Yang W, Yang W, Tiana L (2015) Comparison of temperature lapse rates from the northern to the southern slopes of the Himalayas. Int J Climatol 35:4431-4443

24. Kirchner M, Faus-Kessler T, Jakobi G, Leuchner M, Ries L, Scheele HE, Suppan P (2013) Altitudinal temperature lapse rates in an Alpine valley: Trends and the influence of season and weather patterns. Int J Climatol 33(3):539-555

25. Kitayama K (1996) Climate of the Summit Region of Mount Kinabalu (Borneo) in 1992, an El Niño Year. Moun Res Dev 16:65-75

26. Körner C (1998) A reassessment of high elevation treeline positions and their explanation. Oecologia $115: 445-459$

27. Körner C (1999) Alpine Plant Life: Functional Plant Ecology of High Mountain Ecosystems. Springer, Berlin

28. Körner C, Larcher W (1988) Plant life in cold climates. Society for Experimental Biology. Cambridge University Press, pp 25-57

29. Körner C, Paulsen J (2004) A world-wide study of high altitude treeline temperatures. J Biogeo 31:713-732

30. Liu X, Cheng Z, Yan L, Yin Z (2009) Elevation dependency of recent and future minimum surface air temperature trends in the Tibetan Plateau and its surroundings. Glob Planet Change 68:164-174

31. Liu XD, Chen BD (2000) Climatic warming in the Tibetan Plateau during recent decades. Int J Climatol 20(14):1729-1742

32. Marshall SJ, Sharp MJ, Burgess DO, Anslow FS (2007) Near surface temperature lapse rates on the Prince of Wales Icefield, Ellesmere Island, Canada: Implications for regional downscaling of temperature. Int J Climatol 27(3):385-398

33. Müller H, Whiteman CD (1988) Breakup of a nocturnal temperature inversion in the Dischma Valley during DISKUS. J AppI Meteorol 27:188-194

34. Palazzi E, Filippi L, von Hardenberg J (2017) Insights into elevation-dependent warming in the Tibetan Plateau-Himalayas from CMIP5 model simulations. Climat Dyn 48:3991-4008

35. Pauli H, Gottfried M, Reiter K, Klettner C, Grabherr G (2007) Signals of range expansions and contractions of vascular plants in the high Alps: observations (1994-2004) at the GLORIA master site Schrankogel, Tyrol, Austria. Glob Chang Biol 13:147-156

36. Pepin N (2001) Lapse rate changes in Northern England. Theor Appl Climatol 68:1-16

37. Pepin N, Bradley RS, Diaz HF, Baraer M, Caceres EB et al (2015) Elevation-dependent warming in mountain regions of the world. Nat Clim Chang $5:: 424-430$

38. Pepin N, Losleben M (2002) Climate change in the Colorado Rocky Mountains: Free air versus surface temperature trends. Int J Climatol 22(3):311-329

39. Pepin N, Seidel DJ (2005) A global comparison of surface and free-air temperatures at high elevations. J Geophys Res, 110: D03104 
40. Qin J, Yang K, Liang S, Guo X (2009) The altitudinal dependence of recent rapid warming over the Tibetan Plateau. Clim Change 97:321-327

41. Rangwala I, Miller J, Xu M (2009) Warming in the Tibetan Plateau: possible influences of the changes in surface water vapor. Geophys Res Lett 36:L06703

42. Rangwala I, Miller JR (2010) Twentieth century temperature trends in Colorado's San Juan Mountains. Arct Antar Alp Res 42:89-97

43. Rangwala I, Miller JR (2012) Climate change in mountains: a review of elevation- dependent warming and its possible causes. Clim Change 114(3-4):527-547

44. Rawat GS (2017) The Himalayan Vegetation along horizontal and vertical gradients. In Prins, H.T. \& T. Namgail (Eds.). Pp: 189-204. Bird Migration in the Himalaya. Cambridge University

45. Rolland C (2003) Spatial and seasonal variations of air temperature lapse rates in Alpine regions. J Clim 16(7):1032-1046

46. Sah P, Sharma S (2018) Topographical characterisation of high altitude timberline in the Indian Central Himalayan region. Trop Ecol 59(2):187-196

47. Sharma E et al (2019) Introduction to the Hindu Kush Himalaya Assessment. In: Wester P, Mishra A, Mukherji A, Shrestha A (eds) The Hindu Kush Himalaya Assessment. Springer, Cham

48. Shrestha AB, Wake CP, Mayewski PA, Dibb JE (1999) Maximum temperature trends in the Himalaya and its vicinity: an analysis based on temperature records from Nepal for the period 1971-94. J Clim $12: 2775-2786$

49. Singh SP, Singh RD, Gumber S, Bhatt S (2017) Two principal precipitation regimes in Himalayas and their influence on tree distribution. Trop Ecol 58(4):679-691

50. Stocks BJ, Fosberg MA, Lynham TJ, Mearns L et al (1998) Climate change and forest fire potential in Russian and Canadian boreal forests. Clim Change 38:1-13

51. Tang Z, Fang J (2006) Temperature variation along the northern and southern slopes of Mt. Taibai, China. Agr Fores Met 139:200-207

52. Tetens $O$ (1930) Uber einige meteorologische begrie. J Geophy 6:297-309

53. Thayyen RJ, Dimri AP (2014) Factors controlling slope environmental lapse rate (SELR) of temperature in the monsoon and cold-arid glaciohydrological regimes of the Himalaya. The Cryos Discus 6:5645-5686

54. Thyer N (1985) Looking at western Nepal's climate. Bull Amer Met Soc 66(6):645-650

55. Walther GR, Beißner S, Pott R (2005) Climate change and high mountain vegetation shifts. In Mountain ecosystems Springer, Berlin, Heidelberg. pp:77-96

56. Wang T, Ren HB, Ma KP (2005) Climatic signals in tree ring of Picea schrenkiana along an altitudinal gradient in the central Tianshan Mountains, northwestern China. Trees-Stru Funct 19:735-741

57. Wester P, Mishra A, Mukherji A, Shrestha AB (eds) (2019) The Hindu Kush Himalaya AssessmentMountains, Climate Change, Sustainability and People. Springer Nature Switzerland AG, Cham 
58. Xu J, Grumbine RE, Shrestha A, Eriksson M, Yang X, Wang Y, Wilkes A (2009) The Melting Himalayas: Cascading Effects of Climate Change on Water, Biodiversity, and Livelihoods. Cons Biology 23:520530

59. Yan L, Liu X (2014) Has climatic warming over the Tibetan Plateau paused or continued in recent years? J Earth Ocean Atmos Sci 1:13-28

60. Yan L, Liu Z, Chen G, Kutzbach JE, Liu X (2016) Mechanisms of elevation-dependent warming over the Tibetan Plateau in quadrupled $\mathrm{CO}_{2}$ experimentsxperiments. Clim Change 135:509-519

\section{Figures}

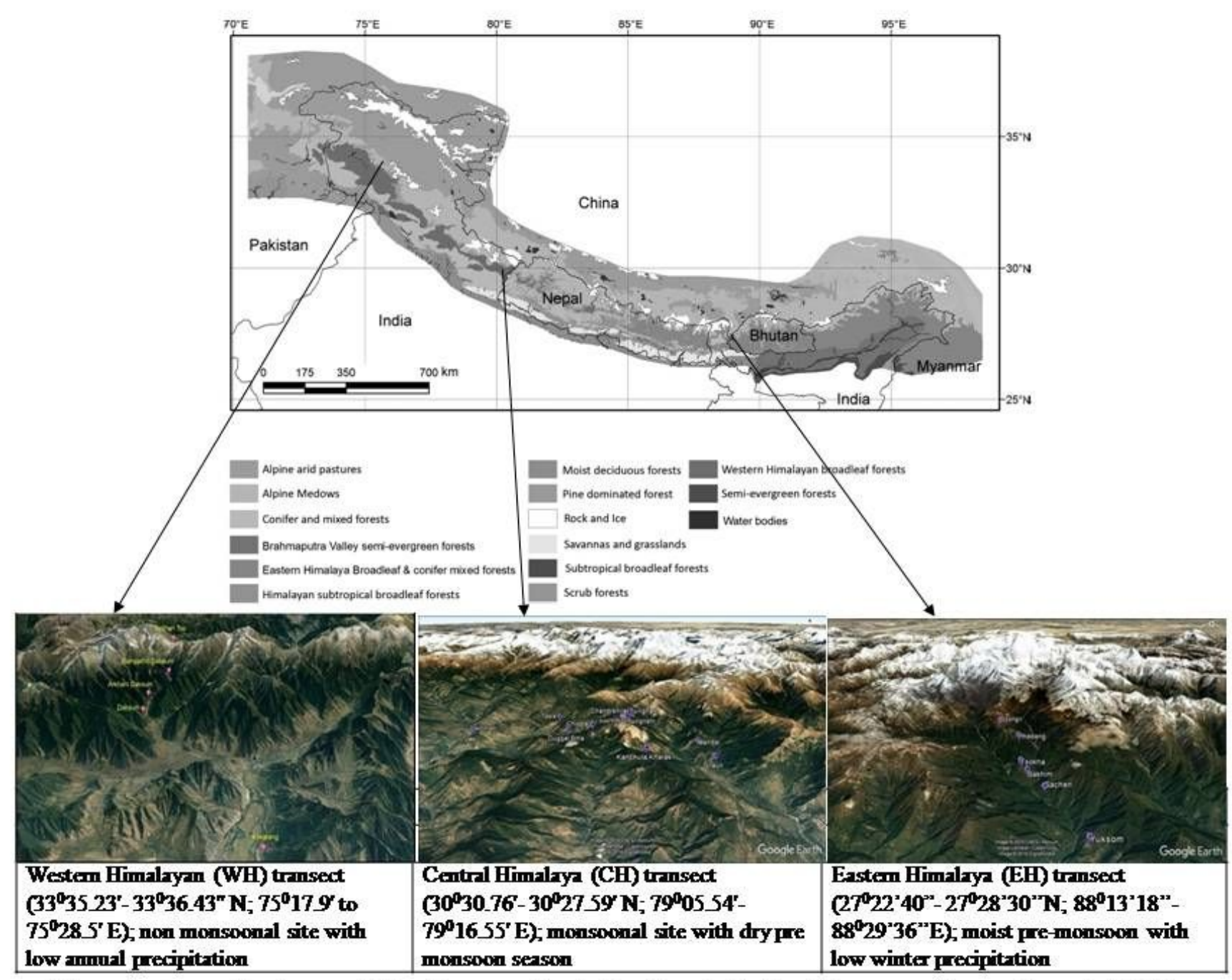

Fignre 1. Generalized map ofHimalayan region indicatingstudy sites (Base map Source: Rawat, 2017)

\section{Figure 1}

"See image above for figure legend" 


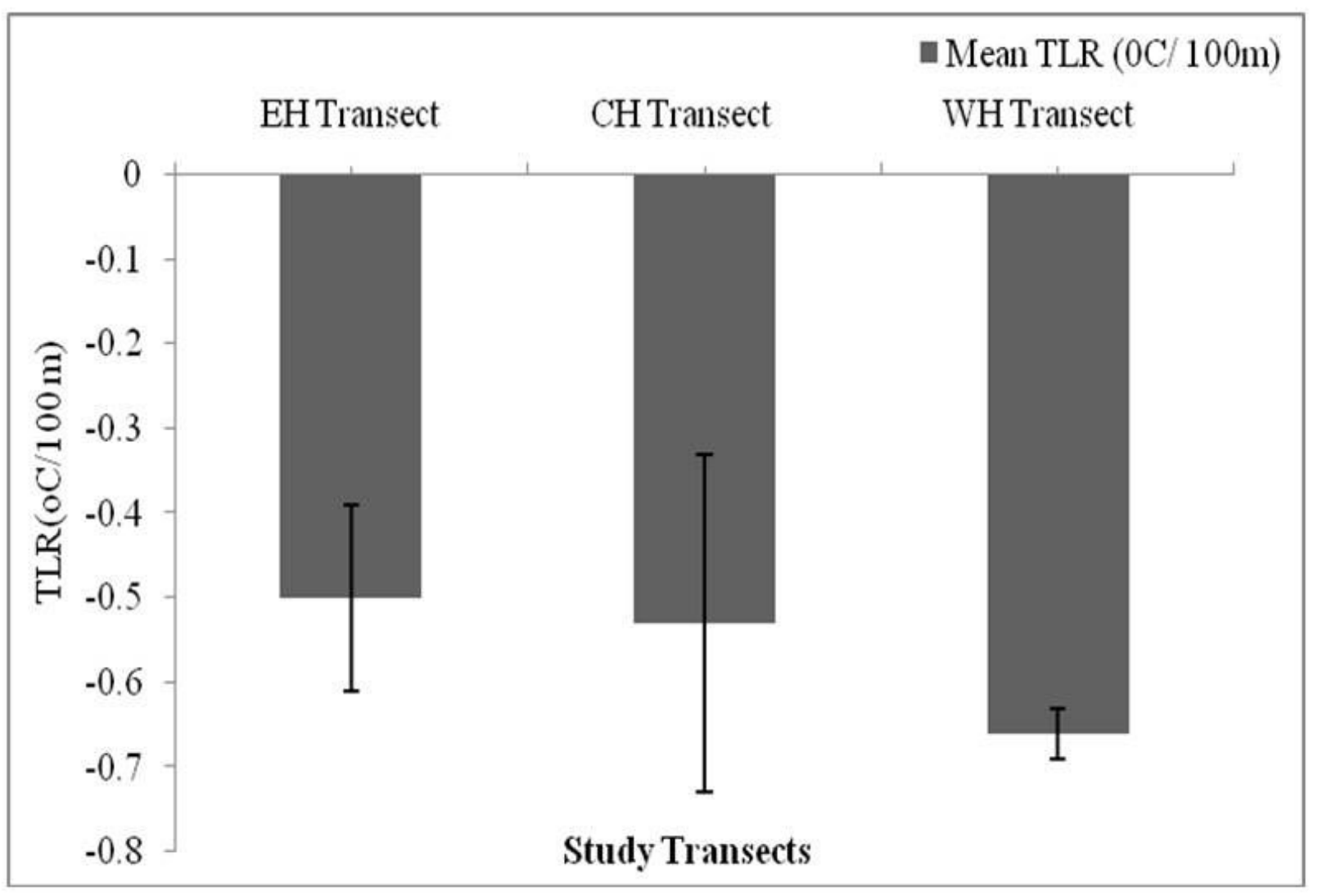

Fignre 2. Variation in mean TIRs across threestudy transects in Himalaya

Figure 2

"See image above for figure legend" 


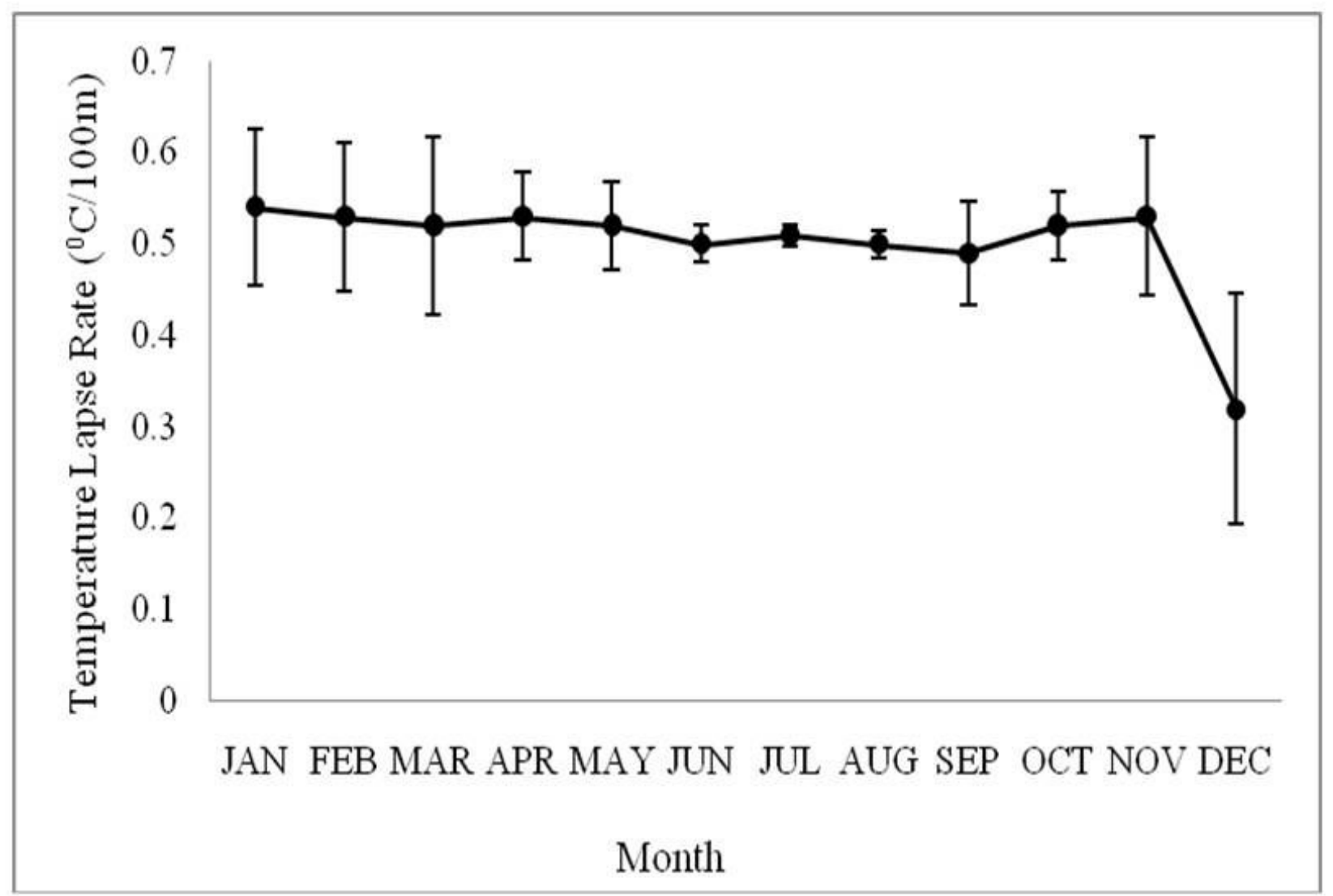

Fignre 3.Monthly variation in TemperatureLapse Rates for EH transect

Figure 3

"See image above for figure legend" 


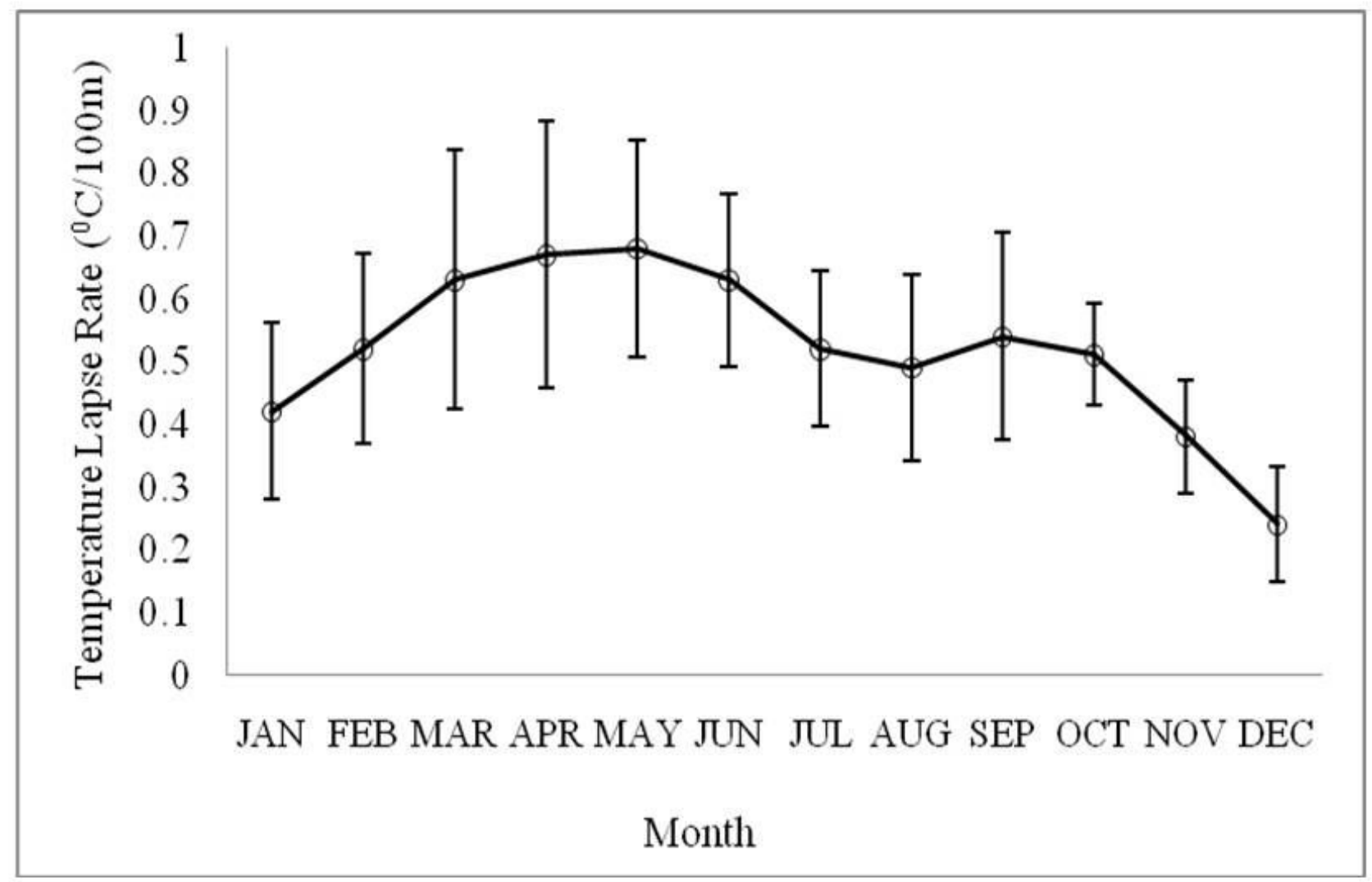

Fignre 4. Monthly variation in TemperatureLapse Rates for CH transect

Figure 4

"See image above for figure legend" 


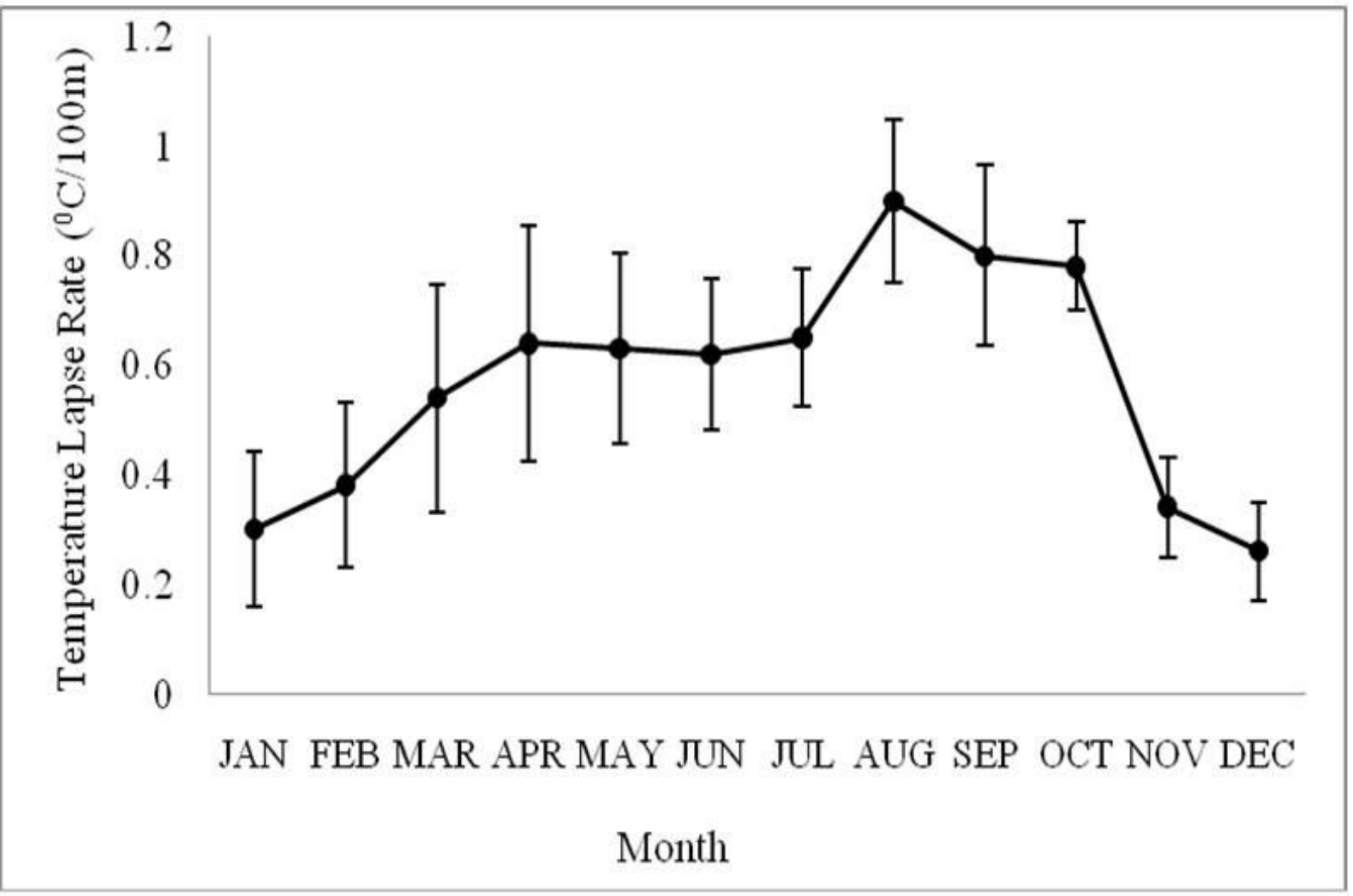

Fignre 5. Monthly variation in TemperatnreLapse Rates for WH transect

Figure 5

"See image above for figure legend" 


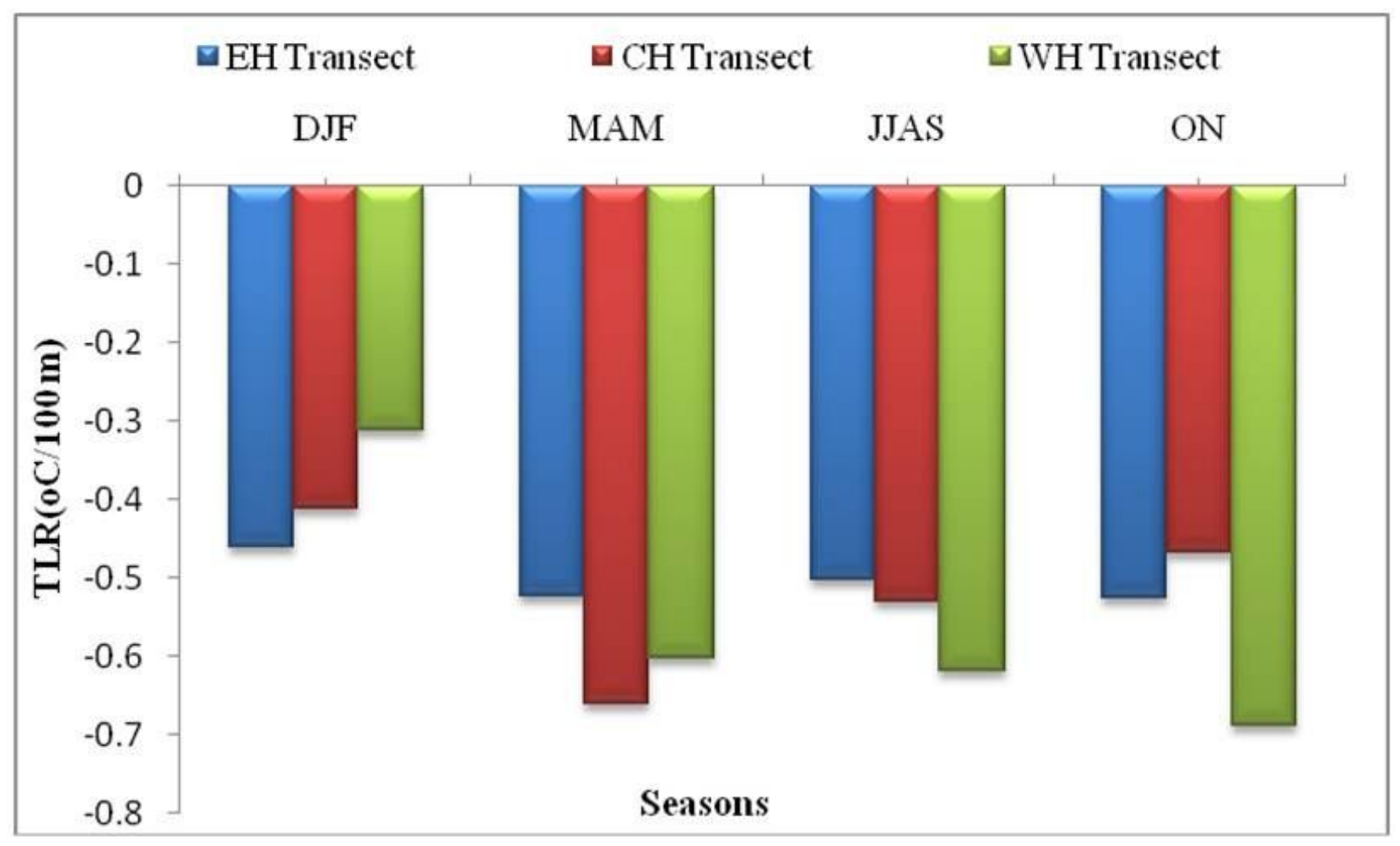

Fignre6. Variation in mean TLRs in four season across threestudy sites

Figure 6

"See image above for figure legend" 


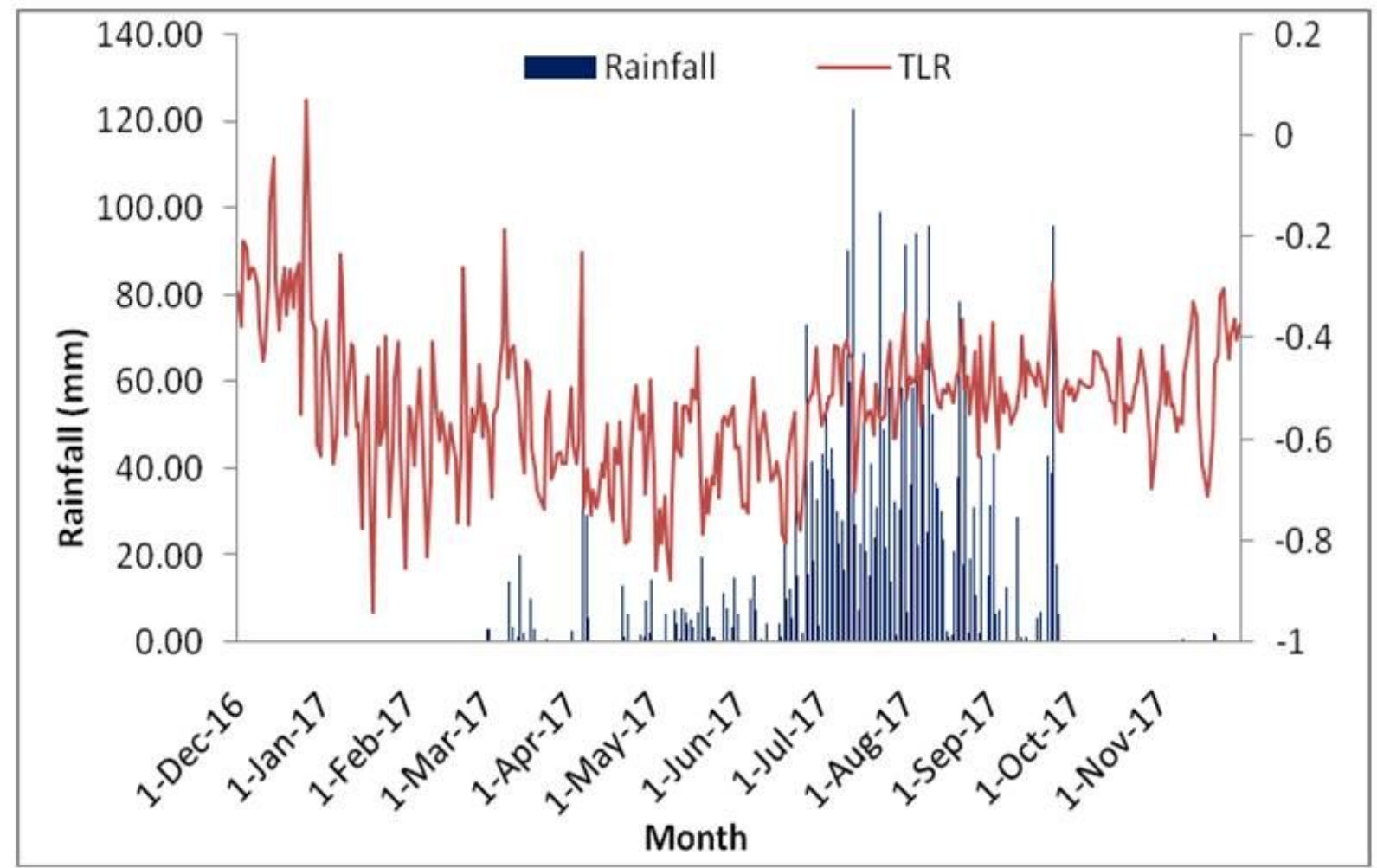

Fignre 7. Daily observed rainfall (in solid bars) and mean estimates TLR (in solid line) for CH transect

Figure 7

"See image above for figure legend" 


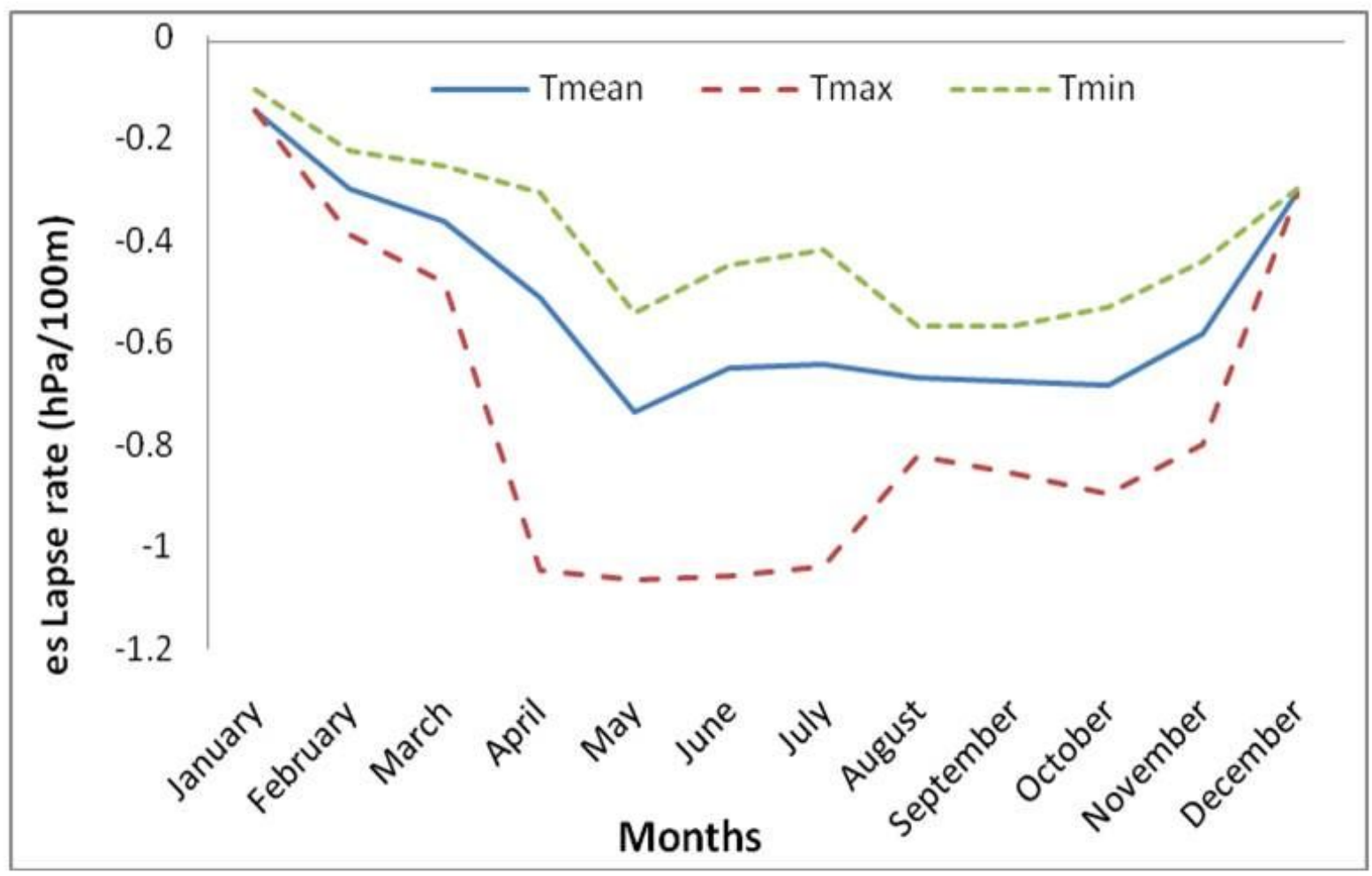

Fignre 8. Annual cycle of mean, maximnm, and mean saturation vapor pressune $\left(\mathrm{e}_{\mathrm{z}}\right)$ lapse rates for $\mathrm{CH}_{\text {transect }}$

\section{Figure 8}

"See image above for figure legend" 


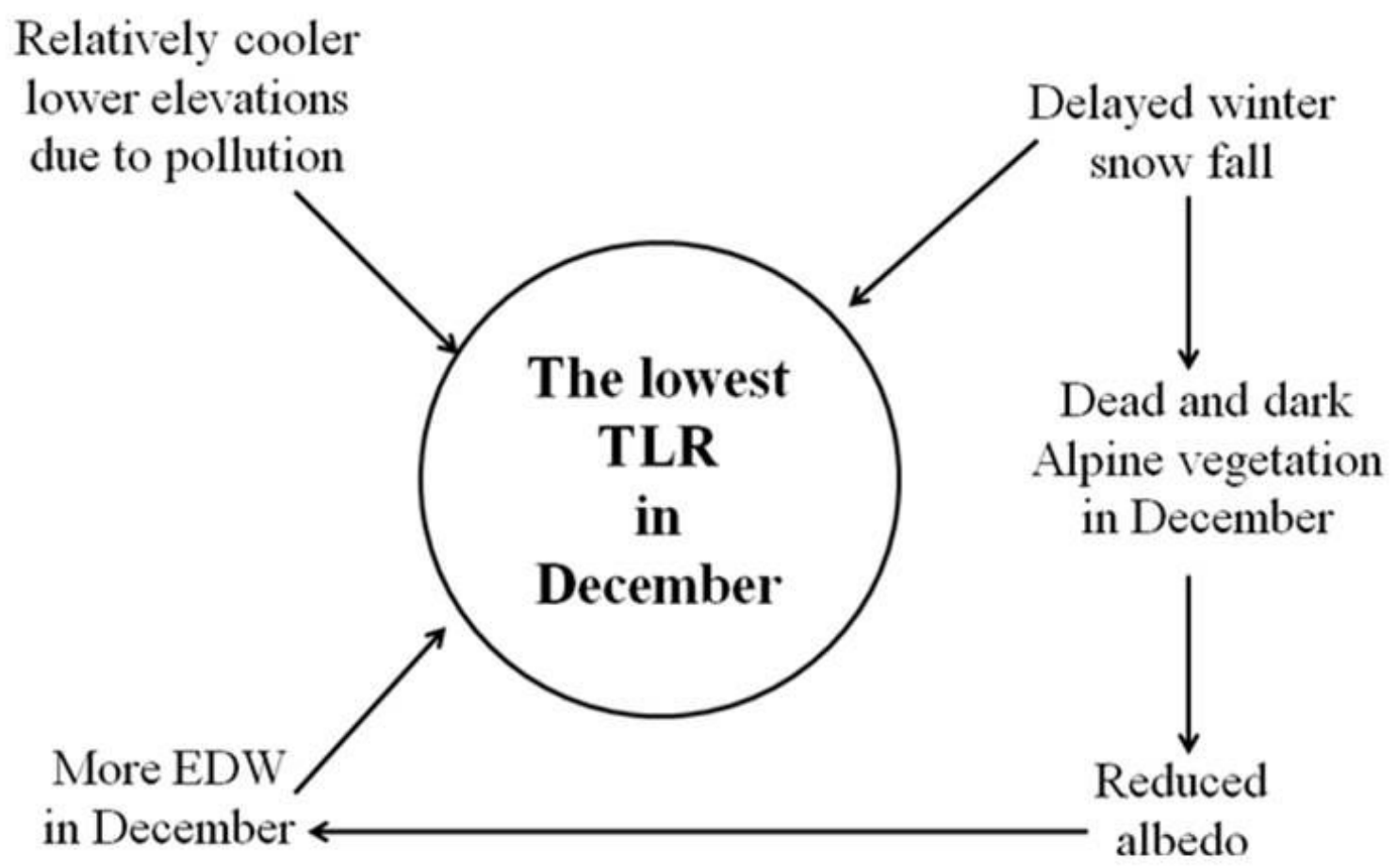

Fignre 9. Factors cansing decrease in December TLR in Himalayas

Figure 9

"See image above for figure legend" 